Research Article

\title{
Influence of Biodiesel Waste Cooking Oil on Produce Hydrocarbon Fraction by Catalytic Cracking Waste Polystyrene and its Application in Gasoline Engine
}

Hendro Juwono*, Ardita Elliyanti, Firman Satria Pamungkas, Anas Assari, Ahmad Hawky Dermawan, Arifah Nurfitriyah

Department of Chemistry, Faculty of Science, Institut Teknologi Sepuluh Nopember, Surabaya, Indonesia, 60111

\section{ARTICLE INFO}

Article History

Received 6 November 2019

Revised 13 December 2019

Available online 31 December 2019

* Email of author corresponding:

hjachmad@gmail.com

\begin{abstract}
Liquid fuel from polystyrene waste and waste cooking oil biodiesel was successfully obtained through catalytic cracking using Al-MCM-41/Ceramic. The structure, morphology, acidity, and porosity of the catalyst were studied by SEM-EDX, pyridine FTIR, and $\mathrm{N}_{2}$ gas adsorption-desorption. The products of catalytic cracking were analyzed using gas chromatogram-mass spectroscopy (GC-MS). The highest yield was obtained at feedstock variations of $57 \%(P)$ : $43 \%(\mathrm{M})$ with the number of hydrocarbon fractions $\left(<\mathrm{C}_{7}\right)$ is $0.48 \%$, hydrocarbon fraction $\left(\mathrm{C}_{8}-\mathrm{C}_{12}\right)$ is $20.99 \%$, and hydrocarbon fraction $\left(>\mathrm{C}_{12}\right)$ is $78.53 \%$ in the cracking time 1 hours. Physical characteristics were reported in the form of density, flash point, and caloric value respective. The performance of liquid fuels with commercial fuels, Premium (RON 88), and additives of methyl tertiary butyl ether (MTBE) comparisons of $225(\mathrm{~mL}): 750(\mathrm{~mL}): 18.25(\mathrm{~mL})$ respectively produce thermal efficiency on engine use gasoline generator sets was $28.22 \%$ at the load of 2118 Watts. Based on this research, all variations of feedstock produce liquid fuels that are in accordance with SNI 06-3506-1994 concerning the quality of gasoline fuel types.
\end{abstract}

Keywords: Catalytic cracking, polystyrene waste, waste cooking oil, liquid fuel

\section{Introduction}

Polystyrene (PS) is one of material used mostly as plastic. Styrofoam is a trade name that has been patented by Dow Chemical. By its maker, Styrofoam was purchased to be used as an insulator on building construction materials, not as food packaging [1]. Polystyrene foam is produced from a mixture of $90-95 \%$ polystyrene and $5-10 \%$ gas such as $n$-butane or n-pentane [2]. The resulting plastic waste cannot be recycled because of the low rate of degradation so that it gives a bad impact such as air and soil pollution [3]. The mesopore catalyst commonly used in catalytic cracking is MCM-41. With low acidity, the MCM-41 catalyst is less effective for use in catalysts because it had Lewis acid side and there was no Bronsted acid side $[4,5]$. Waste cooking oil can be a source of carbon and hydrogen for liquid fuels for gasoline. First, waste cooking oil was converted to methyl ester using the transesterification process. This process required high temperatures in order to convert triglycerides into fatty acid methyl ester. Waste cooking oil was prepared to remove impurities, air, and high free fatty acids [6]. Addition of additive Methyl Tertiary Butyl Ether (MTBE) did improve the performance of liquid fuels in gasoline engines. MTBE additive as a source of oxygen was expected to improve physical character and thermal efficiency (BTE). Improved performance of a mixture of $10 \%$ liquid fuel with $90 \%$ Research Octane Number (RON) Premium of $0.74 \%$ according to MTBE $2.45 \%$, MTBE was also suitable for increasing value of RON on gasoline engines [6].

Based on the description above, in this study the conversion of PS waste and methyl ester of waste cooking oil was carried out using two heat factors and a catalyst. Heat was used to convert PS plastic waste into gas phase and then passed to Al-MCM-41/Ceramic catalyst. The conversion result then added MTBE additives to improve performance on the 
gasoline engine. The product which produced was tested in order to find the calorific value, density, flash point, and Gas Chromatography-Mass Spectrometer (GC-MS), RON, and Brake Thermal Efficiency (BTE) analysis. The test result was compared with SNI 06-3506-1994 regarding material quality gasoline fuel type.

\section{Materials and Methods}

\subsection{Materials}

The materials used in this study were waste cooking oil, polystyrene plastic waste (PS), Al-MCM-41 catalyst from a previous study [7], spark plug ceramic, SAP NaOH catalyst from UPT BPPTK LIPI, methanol p.a. from Merck, Premium. Methyl Tertiary Butyl Ether (MTBE) was purchased from Merck.

\subsection{Synthesis Al-MCM-41/Ceramic Catalyst}

Al-MCM-41/Ceramics catalyst [8] was synthesized by hydrothermal technique using the wet impregnation method according to the previous research procedure [9].

\subsection{Characterization Al-MCM-41/Ceramic Catalyst}

The acidity of the sample was determined by saturated vapor from pyridine absorption and analyzed using FTIR (Fourier-transform Infrared), while SEM-EDX (Scanning Electron Microscope - Energy Dispersive X-ray) was used to identify the morphology. Measurements of $\mathrm{N}_{2}$ absorption from calcined samples were carried out using Tristar II 3020 .

\subsection{Biodiesel Synthesis from Waste Cooking Oil}

The synthesis of liquid fuel was carried out in a reflux reactor at a temperature of $60^{\circ} \mathrm{C}$ and a speed of $800 \mathrm{rpm}$ with the addition of sodium hydroxide and methanol p.a. Biodiesel products were collected at Erlenmeyer.

\subsection{Liquid Fuel Synthesis from Polystyrene Oil Waste}

Liquid fuel synthesizes were carried out in continuous reactor. The resulting products were accommodated at Erlenmeyer. Repetition of the use of catalysts were applied to obtain PM50, PM57, PM67 samples in Table 1. After that, hydrocarbon fuels were mixed with Premium RON 88 and MTBE additives to produce optimum performance in the gasoline engine.

Table 1. Liquid Fuel Composition

\begin{tabular}{ccc}
\hline Feedstock Type & Polystyrene Cracking $(\mathrm{mL})$ & Biodiesel WCO $(\mathrm{mL})$ \\
\hline P50 & 500 & 500 \\
P57 & 571 & 429 \\
P67 & 670 & 330 \\
\hline
\end{tabular}

\subsection{Catalyst Preparation}

The Al-MCM-41 catalyst was mixed with ceramic powder with a mass ratio of 7:3. Nine grams of the pellet catalyst mixture were inserted into a catalyst tube filled with glass wool [10].

\subsection{Liquid Fuel Mixed Characterization}

A mixture of liquid fuels to be characterized in Table 2. Characterization of hydrocarbon fuels including test density, calorific value and flash point [11]. Component analysis of chemical compounds was carried out using GC-MS. The performance test of the mixture of liquid fuels was carried out using a Generator Set (Yanmar, Type TF55R) engine to determine the efficiency value of a mixture of liquid fuels for loading generated during the combustion process in the engine.

Table 2. Liquid Fuel Mixed Composition

\begin{tabular}{ccccc}
\hline Feedstock Type & Feedstock $(\mathrm{mL})$ & Premium RON 88 $(\mathrm{mL})$ & MTBE $(\mathrm{mL})$ & Mixed Liquid Fuel \\
\hline P50 & 225 & 750 & 18.375 & CB50 \\
P57 & 225 & 750 & 18.375 & CB57 \\
P67 & 225 & 750 & 18.375 & CB67 \\
\hline
\end{tabular}




\section{Result and Discussion}

\subsection{Liquid Fuel Hydrocarbon Synthesis}

Hydrocarbon fuel synthesized at different volume variation with catalytic conversion processes which last for $2.5 \mathrm{~h}$ refer to the measurement of the volume of hydrocarbon fuel as a result of cracking in each variation shown in Table 3.

Table 3. Liquid Fuel Hydrocarbon Synthesis

\begin{tabular}{ccc}
\hline Feedstock Type & Liquid Fuel $(\mathrm{mL})$ & Plastic Waste $(\mathrm{mL})$ \\
\hline P50 & 646 & 234 \\
P57 & 804 & 71 \\
P67 & 716 & 159 \\
\hline
\end{tabular}

\subsection{Characterization Al-MCM-41/Ceramic Catalyst}

\subsubsection{FTIR-Pyridine}

Acidity in the Al-MCM-41/Ceramic catalyst consisted of Bronsted and Lewis acids. The interaction between the pyridine compound and the active site of the Al-MCM-41/Ceramic catalyst at the wavenumber $1548 \mathrm{~cm}^{-1}$ showed the active site of Bronsted acid with the amount of $0.0311 \mathrm{mmol} / \mathrm{g}$. Whereas the wavenumber $1446 \mathrm{~cm}^{-1}$ with the amount of 0.0342 $\mathrm{mmol} / \mathrm{g}$ shows the interaction between the pyridine compound and the active site Al-MCM-41/Ceramic which was considered Lewis acid $[8,11]$. These results are summarized in Figure 1.

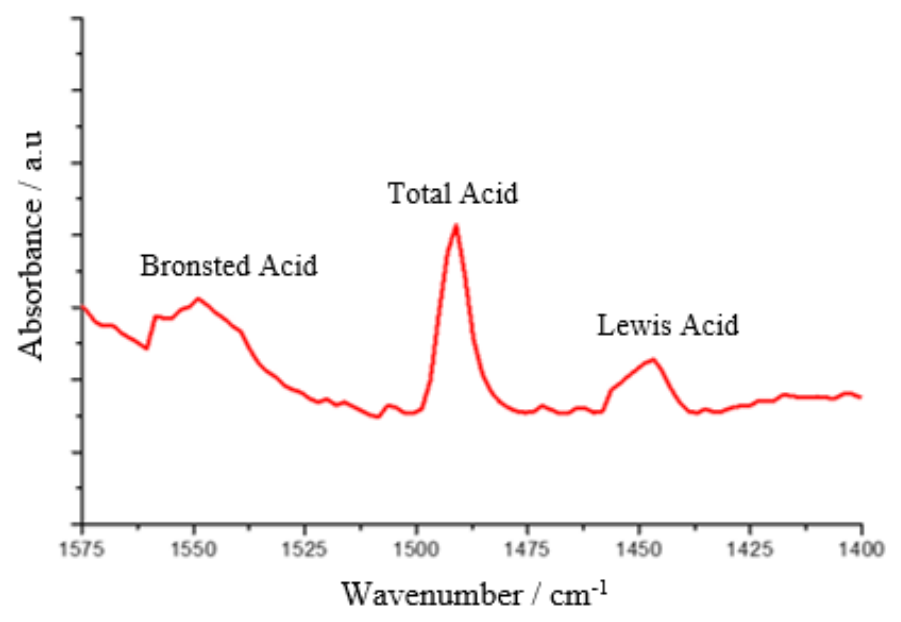

Figure 1. Spectra FTIR-Pyridine Al-MCM-41/Ceramic catalyst

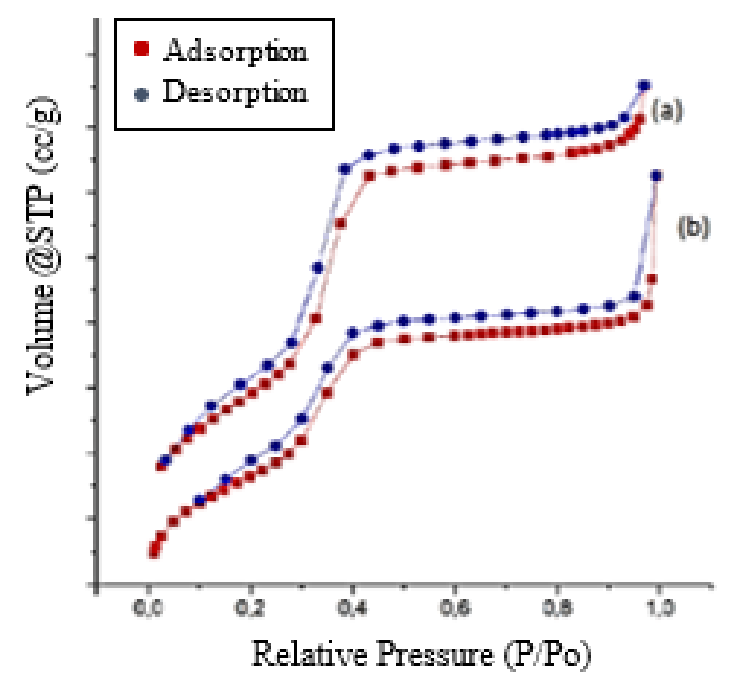

Figure 2. (a) Isotherm graphic of Al-MCM-41 catalyst reference, (b) Isotherm graphic of Al-MCM-41/Ceramic catalyst 


\subsubsection{Adsorption-Desorption $\mathrm{N}_{2}$}

Figure 2 showed the type IV isotherm Langmuir which corresponded to the typical Al-MCM-41/Ceramic catalyst graph [8]. This result indicated mesopore cause the pore radius is $17 \mathrm{~nm}$. These results verify that the addition of ceramic with a mass ratio of Al MCM-41/Ceramic does not change the type of isotherm chart of Al-MCM-41. The surface area of the catalyst was enlarged from the Al-MCM-41 catalyst previously synthesized by Juwono et al. [10]. So, the addition of ceramic did increase the surface area of Al-MCM-41.

\subsubsection{Scanning Electron Microscopy - Energy Dispersive X-Ray Spectroscopy (SEM-EDX)}

In the SEM result, Al-MCM-41 attached to the surface of the ceramic. The morphology of Al-MCM-41 was shown in Figure 3(a) and the appearance of ceramic was showed in Figure 3(b). In pure Al-MCM-41, a smooth surface agglomerated the solid with a hexagonal structure (Figure 3(a) A), while the Al-MCM-41/Ceramic catalyst contained fine particle with a hexagonal structure attached to the ceramic surface (Figure 3(b) yellow circle) which functioned as a supporting solid.

EDX analysis results provide information about the chemical composition of the catalyst as shown in Figure 4. Addition of spark plug ceramic can increase the composition of silica and aluminium [10,12]. The increase in the composition of the two metals can be used for the selectivity of the catalyst. High selectivity catalysts were needed for catalytic cracking reaction processes that have more than one product and byproduct [13].

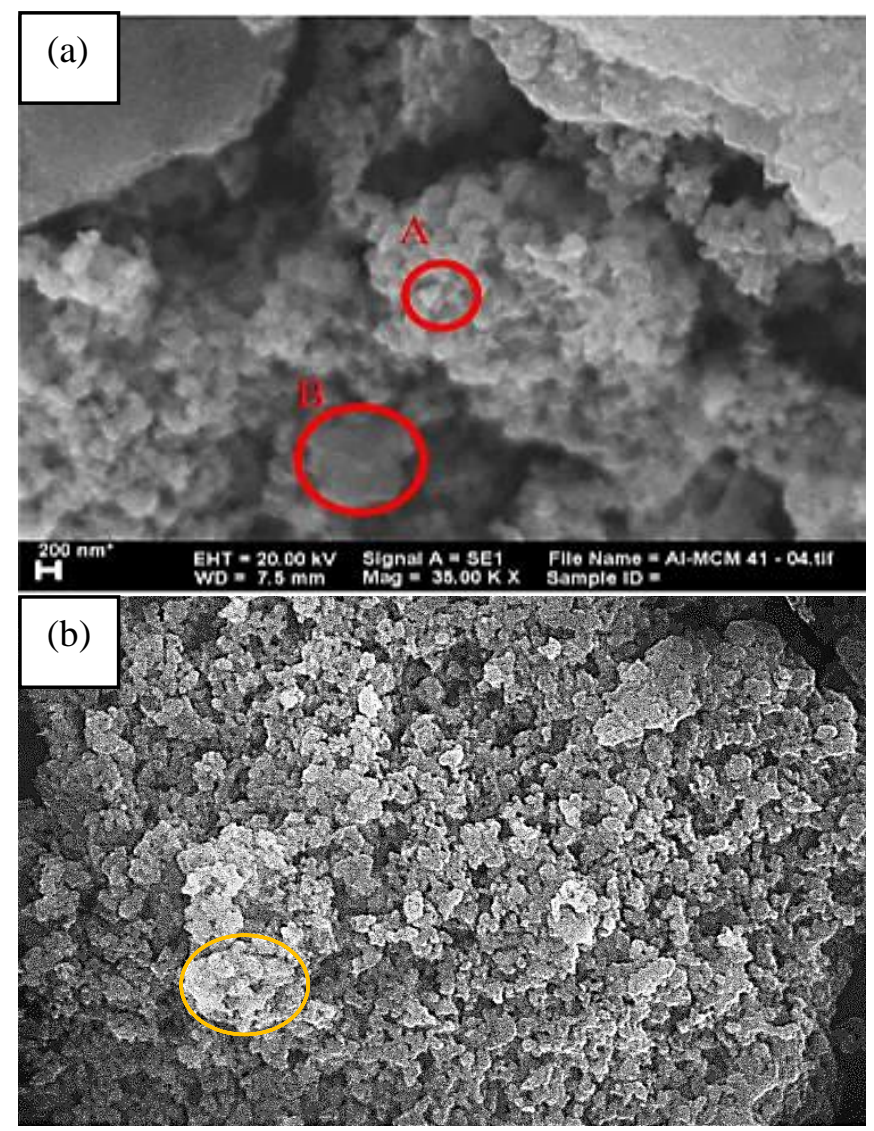

Figure 3. (a) Microgram of SEM Al-MCM-41 catalyst, (b) Microgram of SEM Al-MCM-41/Ceramic catalyst
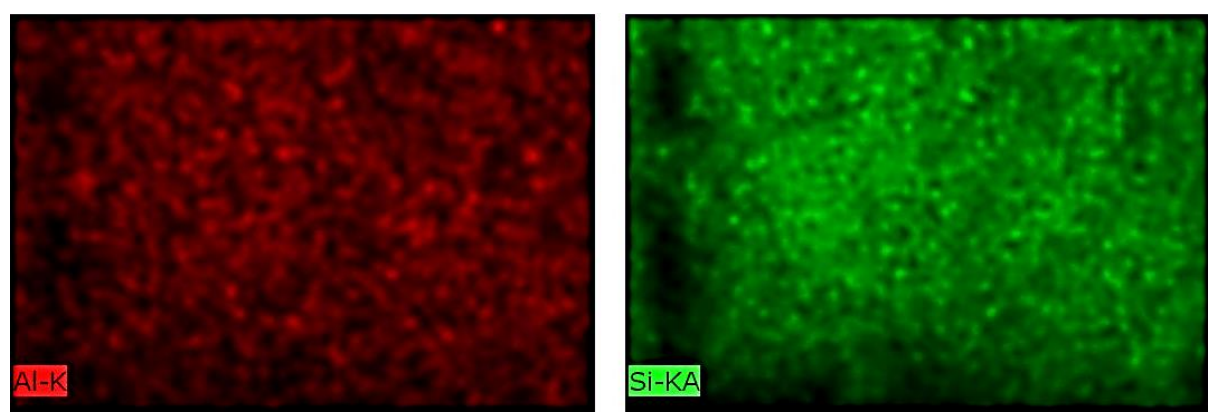

Figure 4. EDX Al-MCM-41/Ceramic Catalyst 


\subsection{Characterization Liquid Fuel Mixed}

\subsubsection{Density Calculation}

The results of determining the density of liquid fuel from cracking with variations in the volume $\%$ of plastic reactants and used cooking oil in Figure 5. The addition of used cooking oil biodiesel, there was an increase in density because the higher used cooking oil biodiesel, the molecular weight (Mw) of the compounding compound liquid fuel was getting bigger [9]. All mixtures of liquid fuels of this research product have met the criteria based on SNI 06-3506-1994 regarding Premium fuel types.

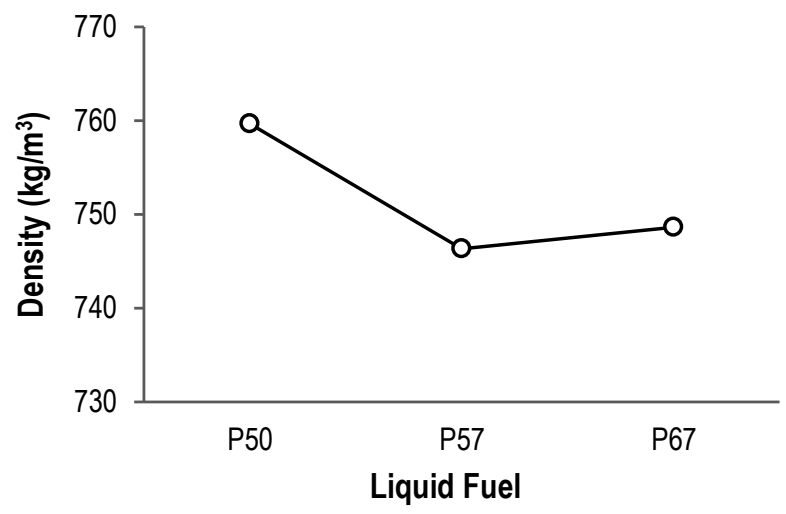

Figure 5. Liquid fuel product density

\subsubsection{Caloric Value Calculation}

The results of measurements of the calorific value of liquid fuel from plastic cracking with used cooking oil and liquid fuel mixture were shown in Figure 6. The calorific value of liquid fuel mixture cracking P50 shown the highest calorific value of $19226.472 \mathrm{Kcal} / \mathrm{kg}$. Addition of polystyrene cracking mixture and used cooking oil biodiesel did increase the calorific value of liquid fuel due to the increasing amount of oxygen content in liquid fuel [14]. All liquid fuel mixtures resulted from catalytic cracking were above the premium standard (RON 88) of $9595.990 \mathrm{Kcal} / \mathrm{kg}$ so as to provide greater energy for efficiency testing on gasoline engines.

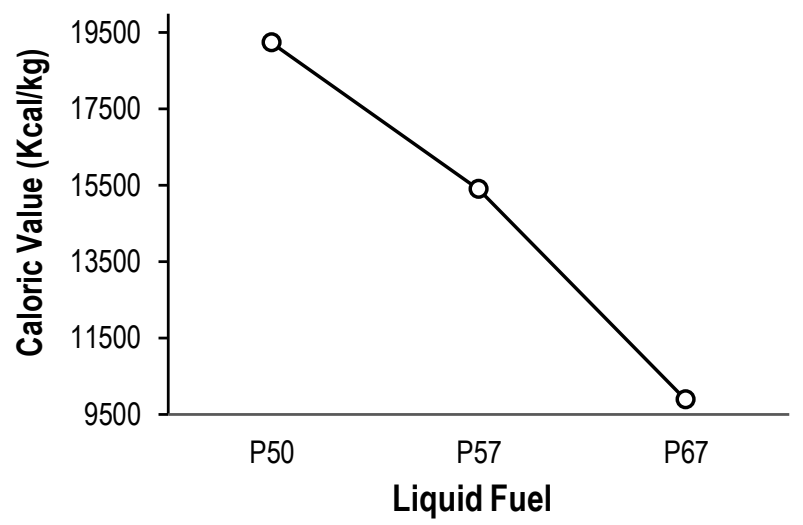

Figure 6. Liquid fuel caloric value

\subsubsection{Flash Point}

Flash points on each variation of the composition of reactants and co-reactants were shown in Figure 7. P57 liquid fuel mixture have the highest flash point at a temperature of $-55.112^{\circ} \mathrm{C}$. Flash points of mixed liquid fuel tend to decreased with the addition of commercial fuels such as diesel [15]. The higher the fuel flash point, the more difficult it was to burn. Fuel with a high flash point was safer in use and storage because it would not be easy to be burned at room temperature. 


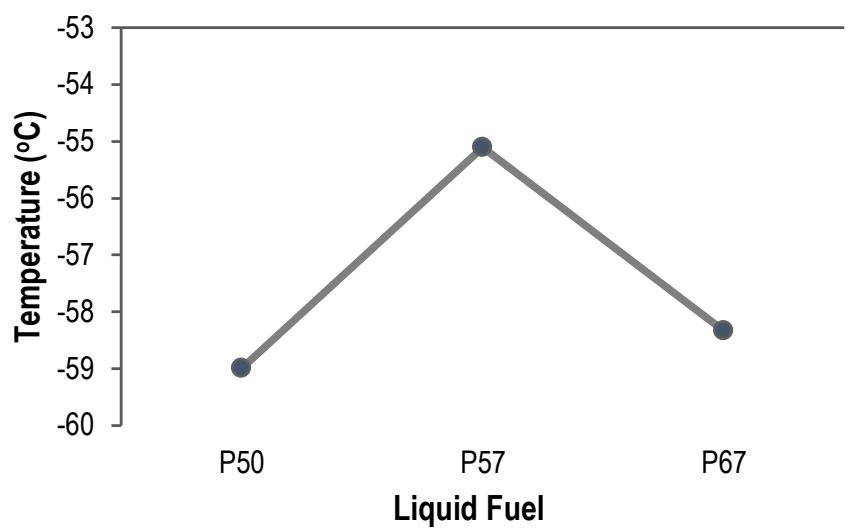

Figure 7. Liquid fuel flash point

\subsection{Liquid Fuel Hydrocarbon Catalytic Cracking Result by GC-MS}

The results of the catalytic cracking of liquid fuel hydrocarbons through GC-MS were shown in Figure 8. The composition of \% hydrocarbon yield obtained in each variation were shown in Figure 9. An increase in the gasoline fraction $\left(\mathrm{C}_{8}-\mathrm{C}_{12}\right)$ and short chain hydrocarbon fractions $\left(<\mathrm{C}_{7}\right)$ along with the addition of cracking and co-reacting time of used cooking oil biodiesel in various variations. There was a decrease in gasoline fraction $\left(\mathrm{C}_{8}-\mathrm{C}_{12}\right)$ for variation of P67 along with the addition of cracking time. This was possible because the reaction between the gas produced by PS plastic cracking and used cooking oil biodiesel was lower so that the reaction tendency was become saturated as additional cracking time was pushed more strongly to form long chain hydrocarbon fractions $[7,16,17]$.

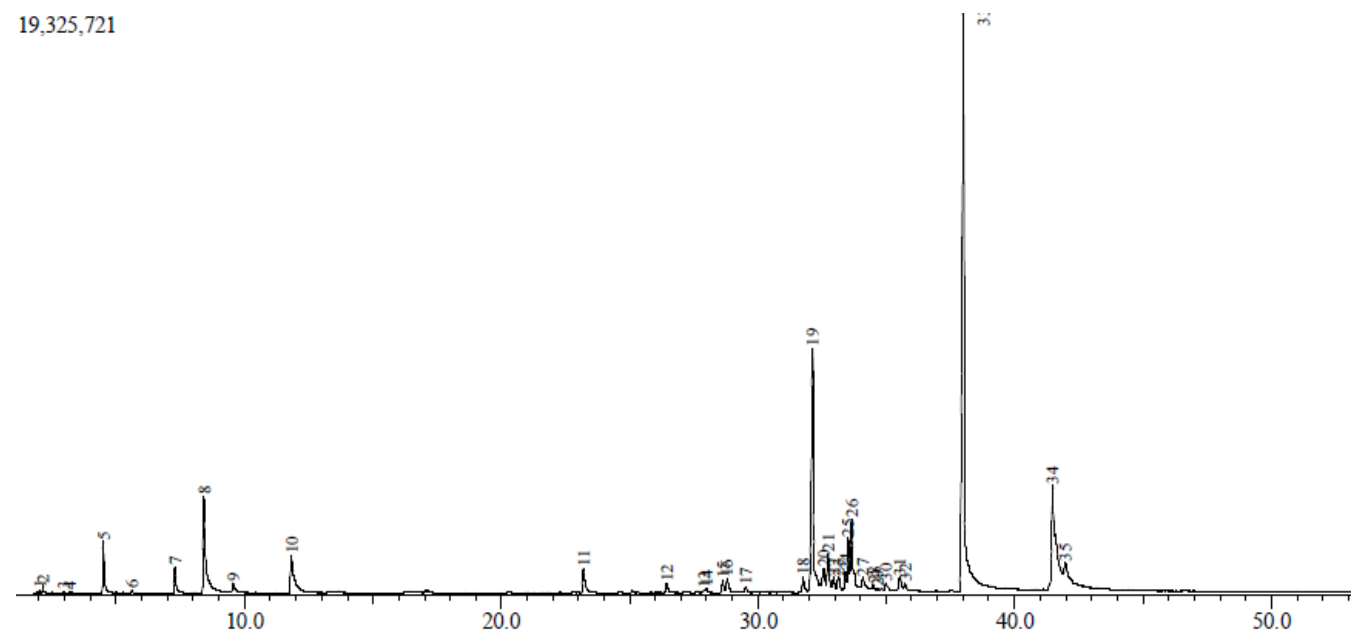

$\ll$ Target $\gg$

Line\#:33 R Time: 38.000 (Scan\#:4345) MassPeaks:49

RawMode:Averaged 37.992-38.008(4344-4346) BasePeal: 74.00(3467410)

BG Mode:Calc. from Peak Group 1 - Event 1

${ }^{100}$ -

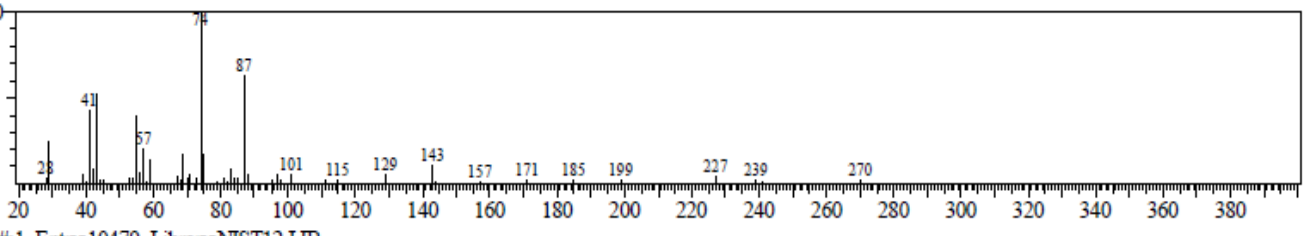

Hit\#.1 Entry.10479 Library:NIST12.LIB

SI:95 Fomnla:C19H38O2 CAS:112-61-8 MolWeight:298 RetIndex:0

CompName:Octadecanoic acid, methyl ester

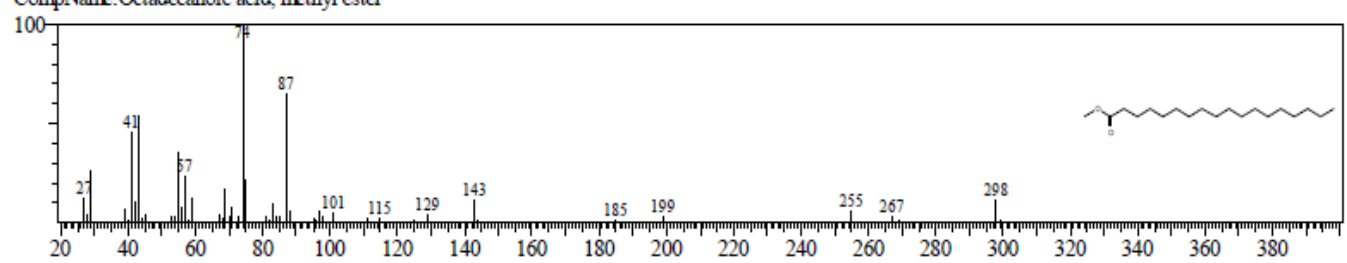

Figure 8. Hydrocarbon chain fraction characterization of GC-MS result 


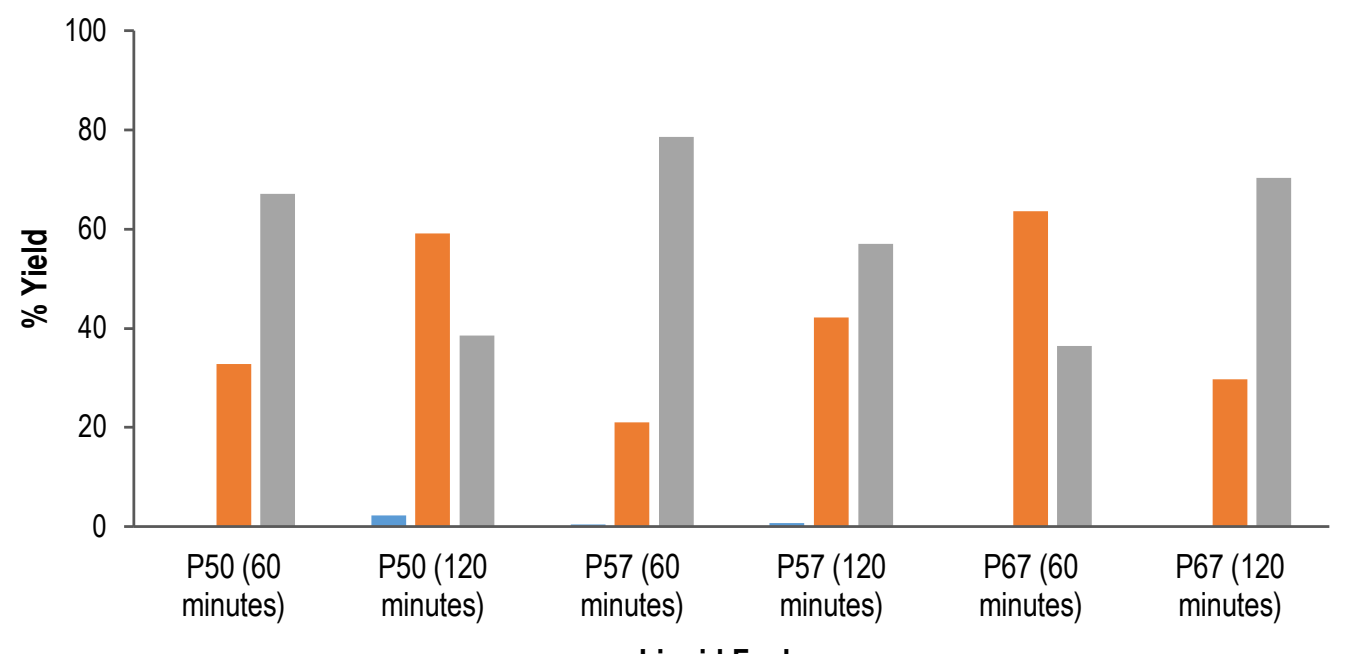

Liquid Fuel

Figure 9. Liquid fuel hydrocarbon fraction $<\mathrm{C}_{7}(\square), \mathrm{C}_{8}-\mathrm{C}_{12}(\square),>\mathrm{C}_{12}(\square)$

\subsection{Liquid Fuel Performance}

Gasoline generator set was used to measure the Brake Thermal Efficiency (BTE) parameter which stated the conversion of heat energy into mechanical energy in gasoline engines. Percentage of thermal efficiency of liquid fuel mixture increased with increasing load (Watt) on gasoline engines as shown in Figure 10. Percentage of premium thermal efficiency of RON 88 and MTBE at loading of 2145 Watts was known to be $25.75 \%$. A mixture of liquid fuels with variations of the P57 feedstock has the largest thermal efficiency of $28.22 \%$ at the load of 2118 Watts. This increase in the percentage of thermal efficiency was caused by an increase in the value of GC-MS from the mixture of liquid fuels [18].

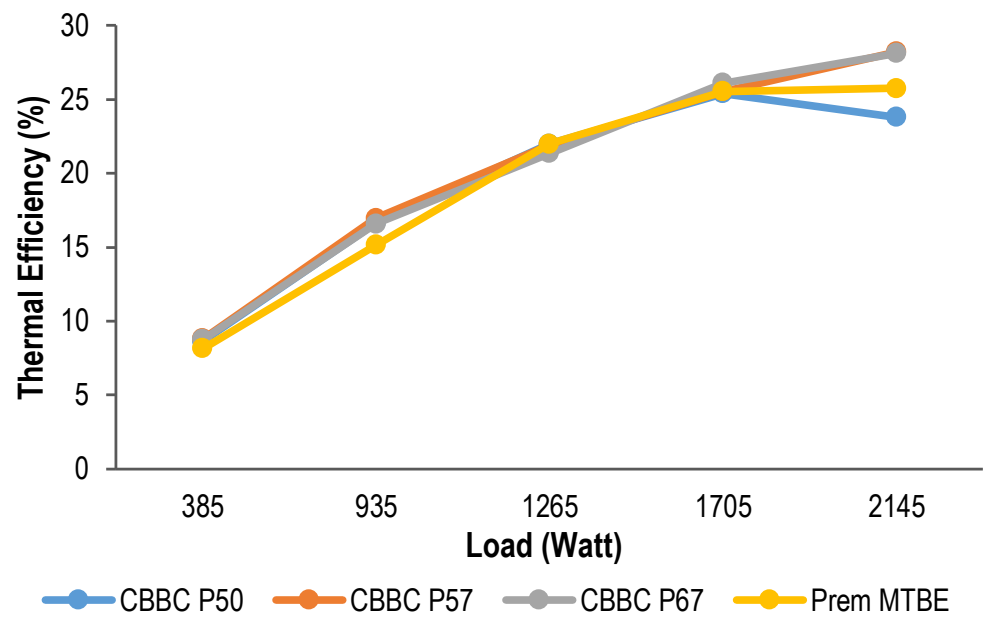

Figure 10. Liquid fuel Brake Thermal Efficiency (BTE)

\section{Conclusion}

Based on research on the determination of liquid fuel characteristics and performance of hydrocarbon fractions as a result of catalytic cracking of used cooking oil biodiesel with polystyrene waste, it can be concluded that the largest \% yield was obtained from variation of P57 feedstock. Liquid fuels characterization and performance, namely density, flash point, calorific value, and BTE in these variations shown the optimum value. Based on this research, all variations of feedstock produce liquid fuels that were in accordance with SNI 06-3506-1994 concerning the quality of gasoline fuel types.

\section{Acknowledgement}

The authors gratefully acknowledge the funding support from ITS Local Scheme of Grants as well as Higher Education Director of Republic Indonesia for Financial Grant in 2019. 


\section{References}

[1] J. C. Chao \& D. T. A. Huibers, "Catalytic Hydrogenation of Glucose to Produce Sorbitol," U. S. Patent 4322569, 3 December, 1982.

[2] M. Heydariaraghi, S. Ghorbanian, A. Hallajisani, \& A. Salehpour, "Fuel Properties of the Oils Produced from the Pyrolysis of Commonly-used Polymers: Effect of Fractionating Column," Journal of Analytical and Applied Pyrolysis, vol. 121, pp. 307-317, 2016.

[3] R. Lin \& R. L. White, "Acid Catalyzed Cracking of Polystyrene," Journal of Applied Polymer Science, vol. 63, no. 10, 1997.

[4] Y. Zhao, Y. Wang, D. Duan, R. Ruan, L. Fan, Y. Zhou, L. Dai, J. Lv, \& Y. Liu, "Fast Microwave-assisted Ex-catalytic Co-pyrolysis of Bamboo and Polypropylene for Bio-oil Production," Bioresource Technology, vol. 249, pp. 69-75, 2018.

[5] S. Endud, H. Nur, \& H. Hamdan, "Probing the Active Sites of Aluminated Mesoporous Molecular Sieve MCM-41 by Secondary Synthesis in the Conversion of Cyclohexanol," in Mesoporous Molecular Sieves 1998. L. Bonneviot, F. Béland, C. Danumah, S. Giasson, \& S. Kaliaguine, Eds. Amsterdam, Netherland: Elsevier, 1998.

[6] T. Topgül, "The Effects of MTBE Blends on Engine Performance and Exhaust Emissions in a Spark Ignition Engine," Fuel Processing Technology, vol. 138, pp. 483-489, 2015.

[7] H. Juwono, T. Triyono, S. Sutarno, \& E. T. Wahyuni, "The Influence of Pd Impregnation into Al-MCM-41 on the Characters and Activity for Biogasoline Production by Catalytic Hydrocracking of FAMEs from Nyamplung Seed Oil (Calophyllum inophyllum)," Indonesian Journal of Chemistry, vol. 13, no. 2, pp. 171-178, 2013.

[8] H. Juwono, T. Triyono, S. Sutarno, E. T. Wahyuni, I. Ulfin, \& F. Kurniawan, "Production of Biodiesel from Seed Oil of Nyamplung (Calophyllum inophyllum) by Al-MCM-41 and Its Performance in Diesel Engine," Indonesian Journal of Chemistry, vol. 17, no. 2, pp. 316-321, 2017.

[9] H. Juwono, T. Triyono, S. Sutarno, E. T. Wahyuni, H. Harmami, I. Ulfin, \& F. Kurniawan, "Production of Hydrocarbon $\left(\mathrm{C}_{7}-\mathrm{C}_{20}\right)$ from Hydrocracking of Fatty Acid Methyl Esters on Pd/Al-MCM-41 Catalyst," Bulletin of Chemical Reaction Engineering \& Catalysis, vol. 12, no. 3, pp. 337-342, 2017.

[10] H. Juwono, L. Fauziah, I. Q. Uyun, R. Alfian, Suprapto, Y. L. Ni'mah, \& I. Ulfin, "Catalytic Convertion of Al-MCM-41Ceramic on Hidrocarbon $\left(\mathrm{C}_{8}-\mathrm{C}_{12}\right)$ Liquid Fuel Synthesis from Polypropylene Plastic Waste," in AIP Conference Proceedings on the $3^{\text {rd }}$ International Seminar on Chemistry, pp. 1-7, 2018.

[11] H. Juwono, M. A. T. Sujadmiko, L. Fauziah, \& I. Q. Ayyun, "Catalytic Conversion from Plastic Waste by Silica-AluminaCeramic Catalyst to Produce an Alternative Fuel Hydrocarbon Fraction," Jurnal ILMU DASAR, vol. 20, no. 2, pp. 8388, 2019.

[12] Y. Kosivtsov, E. Sulman, Y. Lugovoy, A. Kosivtsova, \& A. Stepacheva, "Experimental Investigation of the Biomass Catalytic Pyrolysis Process to Produce the Combustible Gases with the High Calorific Value," Bulletin of Chemical Reaction Engineering \& Catalysis, vol. 10, no. 3, 2015.

[13] I. Kalargaris, G. Tian, \& S. Gu, "Experimental Characterisation of a Diesel Engine Running on Polypropylene Oils Produced at Different Pyrolysis Temperatures," Fuel, vol. 211, pp. 797-803, 2018.

[14] J.J. Li, Name Reaction, A Collection of Detailed Reaction Mechanisms. $3^{\text {rd }}$ Expanded Ed. New York, USA: SpringerVerlag Berlin Heidelberg, 2006.

[15] A. E. Atabani \& A. d. S. César, "Calophyllum inophyllum L. - A Prospective Non-edible Biodiesel Feedstock. Study of Biodiesel Production, Properties, Fatty Acid Composition, Blending and Engine Performance," Renewable and Sustainable Energy Reviews, vol. 37, pp. 644-655, 2014.

[16] S. S. Prabu, M. A. Asokan, R. Roy, S. Francis, \& M. K. Sreelekh, "Performance, Combustion and Emission Characteristics of Diesel Engine Fuelled with Waste Cooking Oil Bio-diesel/diesel Blends with Additives," Energy, vol. 122, pp. 638-648, 2017.

[17] O. Sanahuja-Parejo, A. Veses, M. V. Navarro, J. M. López, R. Murillo, M. S. Callén, \& T. García, "Drop-in Biofuels from the Co-pyrolysis of Grape Seeds and Polystyrene," Chemical Engineering Journal, vol. 377, 2018.

[18] X. Zhang, H. Lei, L. Zhu, M. Qian, X. Zhu, J. Wu, \& S. Chen, "Enhancement of Jet Fuel Range Alkanes from Cofeeding of Lignocellulosic Biomass with Plastics via Tandem Catalytic Conversions," Applied Energy, vol. 173, pp. 418-430, 2016. 